\author{
RESEARCH ARTICLE \\ 10.1029/2019JC015989 \\ Key Points: \\ - In situ production contributes more \\ significantly toward elevating \\ surface methane levels along the \\ MAB compared to seafloor gas seeps \\ - Both in situ production and seafloor \\ gas seeps sampled in this region \\ produce methane through microbial \\ pathways \\ - Methane is rapidly oxidized \\ throughout the water column in the \\ region investigated
}

Supporting Information:

- Supporting Information S1

Correspondence to:

M. Leonte,

mleonte31@gmail.com

Citation:

Leonte, M., Ruppel, C. D., Ruiz-Angulo, A., \& Kessler, J. D. (2020). Surface methane concentrations along the Mid-Atlantic Bight driven by aerobic subsurface production rather than seafloor gas seeps. Journal of Geophysical Research: Oceans, 125, e2019JC015989. https://doi.org/ $10.1029 / 2019 J C 015989$

Received 17 DEC 2019 Accepted 26 MAR 2020 Accepted article online 4 APR 2020

\section{Surface Methane Concentrations Along the Mid-Atlantic Bight Driven by Aerobic Subsurface Production Rather Than Seafloor Gas Seeps}

\author{
Mihai Leonte $^{1}$ iD, Carolyn D. Ruppel ${ }^{2}$ iD, Angel Ruiz-Angulo ${ }^{3}$ iD, and John D. Kessler' ${ }^{1}$ (D) \\ ${ }^{1}$ Department of Earth and Environmental Sciences, University of Rochester, Rochester, NY, USA, ${ }^{2}$ U.S. Geological Survey, \\ Woods Hole, MA, USA, ${ }^{3}$ Icelandic Meteorological Office, Reykjavik, Iceland
}

\begin{abstract}
Relatively minor amounts of methane, a potent greenhouse gas, are currently emitted from the oceans to the atmosphere, but such methane emissions have been hypothesized to increase as oceans warm. Here, we investigate the source, distribution, and fate of methane released from the upper continental slope of the U.S. Mid-Atlantic Bight, where hundreds of gas seeps have been discovered between the shelf break and $\sim 1,600 \mathrm{~m}$ water depth. Using physical, chemical, and isotopic analyses, we identify two main sources of methane in the water column: seafloor gas seeps and in situ aerobic methanogenesis which primarily occurs at 100-200 m depth in the water column. Stable isotopic analyses reveal that water samples collected at all depths were significantly impacted by aerobic methane oxidation, the dominant methane sink in this region, with the average fraction of methane oxidized being 50\%. Due to methane oxidation in the deeper water column, below $200 \mathrm{~m}$ depth, surface concentrations of methane are influenced more by methane sources found near the surface $(0-10 \mathrm{~m}$ depth) and in the subsurface (10-200 m depth), rather than seafloor emissions at greater depths.

Plain Language Summary Methane is a greenhouse gas that is second only to carbon dioxide in its contribution toward modern global warming. Here we investigate the mechanisms responsible for adding and removing methane from ocean waters along the Mid-Atlantic Bight, since future climate change is suspected to increase the release and/or production of methane into the oceans. Our study shows that methane was released at the seafloor from gas seeps in the form of bubbles and produced in surface and subsurface waters. Regardless of the source, methane was observed to be actively removed from these ocean waters through microbial oxidation, helping to limit atmospheric emission, especially for methane originating at greater depths.
\end{abstract}

\section{Introduction}

The increase in radiative forcing due to rising methane $\left(\mathrm{CH}_{4}\right)$ concentrations during the Anthropocene is second only to that of carbon dioxide $\left(\mathrm{CO}_{2}\right)$, making $\mathrm{CH}_{4}$ a driver of ongoing and future climate change (Ciais et al., 2013). Although the global annual emission of $\mathrm{CH}_{4}$ from the oceans to the atmosphere has been estimated to be relatively small (6-12 Tg; Weber et al., 2019), future ocean warming has the potential to increase the input of benthic $\mathrm{CH}_{4}$ to the water column and possibly the atmosphere (Hovland et al., 1993; Ruppel \& Kessler, 2017; Saunois et al., 2016).

Methane sources into seawater include diffusive and ebullitive emissions of microbially derived and thermogenically derived $\mathrm{CH}_{4}$ from the seafloor as well as aerobic in situ production in the oceanic water column (Reeburgh, 2007). Active gas seeps are responsible for high $\mathrm{CH}_{4}$ fluxes in waters where bubbles are emitted from the seafloor and through the water column traversed by the bubble plume (Heeschen et al., 2003; Leonte et al., 2018; McGinnis et al., 2006; Römer et al., 2012). The vertical distance that $\mathrm{CH}_{4}$ can be transported via gas bubbles depends on several factors, including seafloor depth and the bubble diameter at the seafloor (McGinnis et al., 2006; Rehder et al., 2009; Wang et al., 2016). However, only in rare cases is $\mathrm{CH}_{4}$ emitted from the seafloor in gas bubbles likely to reach the sea-air interface (Ruppel \& Kessler, 2017). Instead, $\mathrm{CH}_{4}$ diffuses out of bubbles and dissolves into the water column relatively quickly, being replaced by other gases inside the bubble (Leonte et al., 2018; McGinnis et al., 2006; Rehder et al., 2009; Wang et al., 2016). Further 
vertical transport of the dissolved $\mathrm{CH}_{4}$ occurs at significantly slower rates than those associated with buoyant bubble rise.

Apart from seafloor sediments, $\mathrm{CH}_{4}$ is also produced in the water column through aerobic methanogenesis. Several studies investigating dissolved $\mathrm{CH}_{4}$ in open ocean environments have noted a subsurface $\mathrm{CH}_{4}$ concentration maximum between 100 and $200 \mathrm{~m}$ depths in the water column (e.g., Holmes et al., 2000). However, since methanogenesis has traditionally been considered a strictly anaerobic process, the apparent production of $\mathrm{CH}_{4}$ in oxygenated subsurface waters was termed the "Ocean Methane Paradox" (Holmes et al., 2000; Kiene, 1991; Reeburgh, 2007). Previous studies have examined the fecal pellets formed by zooplankton or other marine organisms as suitable microenvironments where anaerobic conditions, and thus methanogenesis, might occur (Nihous \& Masutani, 2006; Oremland, 1979). More recent studies have identified several pathways for aerobic $\mathrm{CH}_{4}$ production to occur including the cycling of dimethylsulfoniopropionate and the degradation of phosphonates commonly found as part of dissolved organic matter (Damm et al., 2008; Karl et al., 2008; Repeta et al., 2016). Regardless of the source, $\mathrm{CH}_{4}$ concentrations at any depth may be decreased by mixing with lower concentration waters and by microbial oxidation (Leonte et al., 2017; Mau et al., 2012). Since these sink terms appear ubiquitous throughout the water column (e.g., Mau et al., 2012), sources of $\mathrm{CH}_{4}$ at shallower water depths have a greater potential to contribute $\mathrm{CH}_{4}$ to the atmosphere.

Here, our objectives were to quantify the fate of seafloor-released $\mathrm{CH}_{4}$ and determine the relative contribution of seafloor gas seeps versus in situ aerobic methanogenesis to sea surface $\mathrm{CH}_{4}$ concentrations. To investigate these objectives, we collected water samples for $\mathrm{CH}_{4}$ concentration and stable carbon isotopic analysis along the U.S. Mid-Atlantic Bight (MAB) onboard the R/V Hugh R. Sharp from 25 August to 5 September 2017. The combination of dissolved $\mathrm{CH}_{4}$ concentration and stable isotope measurements has been shown to constrain $\mathrm{CH}_{4}$ production pathways (e.g., Whiticar, 1999) and the extent of $\mathrm{CH}_{4}$ oxidation (e.g., Leonte et al., 2017, 2018), and similar analyses were conducted here. This region was chosen due to the recent discovery of over 300 seafloor methane seeps which originate at water depths from 53 to 1,612 m (Skarke et al., 2014). Some of the seeps lie at or within a few hundred meters shallower than the landward limit of gas hydrate stability ( 575 m water depth; Brothers et al., 2013; Skarke et al., 2014). Gas hydrate is a solid, ice-like structure formed by water molecules which can trap $\mathrm{CH}_{4}$ and other gases when sufficiently low temperatures, high pressures, and high $\mathrm{CH}_{4}$ concentrations are found in ocean sediments. Due to their sensitivity to temperature perturbations, upper continental slope gas hydrates are considered susceptible to degradation and $\mathrm{CH}_{4}$ release as ocean waters warm (Berndt et al., 2014; Kvenvolden \& Rogers, 2005; Ruppel, 2011; Ruppel \& Kessler, 2017). In total, we surveyed 25 sampling stations on seven downslope sampling transects along a $230 \mathrm{~km}$ corridor of the upper continental slope between northern Virginia and Cape Hatteras $\left(35.524-37.539^{\circ} \mathrm{N}\right)$ to assess the extent of $\mathrm{CH}_{4}$ oxidation and the distribution of $\mathrm{CH}_{4}$ sources in the water column. Here, we commonly refer to three depth horizons based on the depth where samples were collected: the near surface (0-10 m), the subsurface (10-200 m), and the deeper water column (200 m to seafloor). Since our study area was along the continental slope, the seafloor depth varies among stations.

\section{Materials and Methods}

\subsection{Water Sample Collection and Preparation}

Water samples for this study were collected along seven transects on the MAB upper continental slope during a cruise aboard the R/V Hugh R. Sharp (Figure 1). The transect locations were chosen based on the distribution of $\mathrm{CH}_{4}$ seeps delineated by Skarke et al. (2014) and new water column imaging data collected during this research cruise using the U.S. Geological Survey's Simrad EK80 broadband fisheries echosounder with a $38 \mathrm{kHz}$ transducer (Baldwin et al., 2020). At each station on the sampling transects, water was collected at up to 12 distinct water depths using Niskin bottles arrayed on a conductivity-temperature-depth (CTD) carousel. Temperature, salinity, and density were recorded using a SeaBird Electronics 911 plus CTD for each station, and plots of these data can be found in the supporting information. Three to five stations spanning 136 to 1,025 m water depth comprised each of the transects except for 6 and 7, which consisted of a single station each. In this study, we refer to sample locations as TNSM, where $N$ is the number of the transect and $M$ is the station number. The EK80 imaged the position of the CTD apparatus in the water column during deployments, and CTD casts were designed to intersect or avoid acoustically detectable benthic $\mathrm{CH}_{4}$ plumes, depending on the goal of each measurement. 


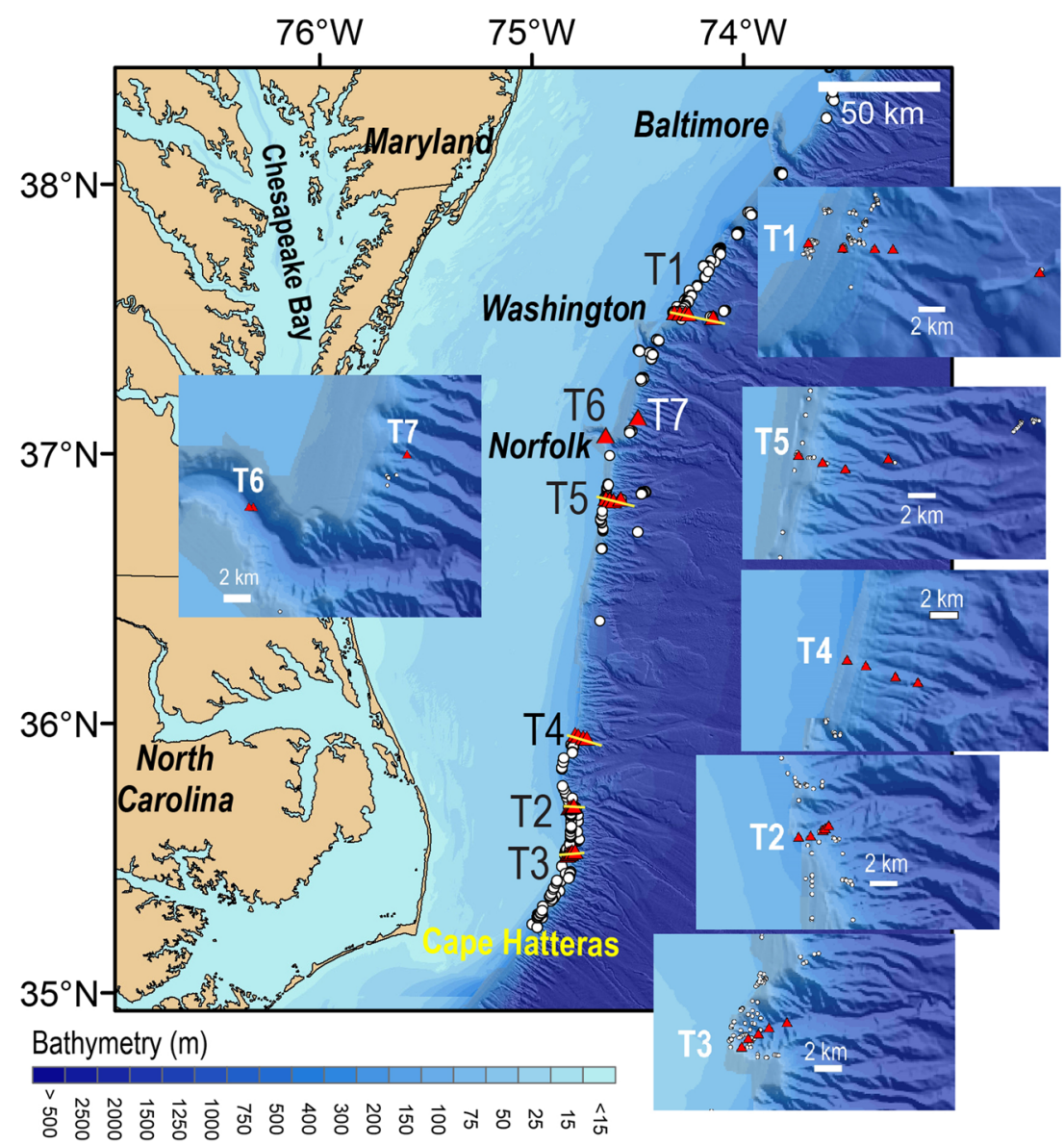

Figure 1. Map of sampling locations along the U.S. Atlantic Margin. In total, seven downslope transects were investigated, T1-T7. Red triangles show individual sampling stations that make up transects along the slope. White dots show gas seeps, either previously identified by Skarke et al (2014) or detected during this cruise (Baldwin et al., 2020).

Using 1/4" Tygon tubing, water samples were transferred from Niskin bottles to $250 \mathrm{ml}$ glass vials (Wheaton) for $\mathrm{CH}_{4}$ concentration analysis and $500 \mathrm{ml}$ glass vials for $\delta^{13} \mathrm{C}_{-} \mathrm{CH}_{4}$ isotopic analysis. Vials were filled from the bottom, and the flow rate of water was controlled to ensure that bubbles did not form within the vial during filling. Water was allowed to overflow in order to flush the vials with at least two vial volumes of water before capping with a butyl rubber stopper and aluminum crimp cap (Wheaton). Immediately after capping, a $10 \mathrm{ml}$ ultrahigh purity nitrogen headspace was introduced into each vial via displacement. Two syringes were used simultaneously, one to inject nitrogen and the other to withdraw an equal volume of water. Mercuric chloride $\left(\mathrm{HgCl}_{2}\right)$ was then added to each vial to halt further biological activity and preserve the samples until analysis. A gastight syringe (Hamilton) was used to add 250 and $500 \mu \mathrm{l}$ of a supersaturated $\mathrm{HgCl}_{2}$ solution to each $\mathrm{CH}_{4}$ concentration vial and each isotopic ratio vial, respectively. Vials filled for $\mathrm{CH}_{4}$ concentration analysis were stored in a temperature-controlled incubator set to $6{ }^{\circ} \mathrm{C}$ to allow the headspace to equilibrate at near-bottom water temperature for at least $12 \mathrm{hr}$ before analysis in the shipboard laboratory. Vials were placed sideways inside the incubator to prevent the headspace gas from escaping through the rubber stopper. Samples meant for isotopic ratio analysis were stored upside down in custom built sample boxes until analysis on shore.

\subsection{Methane Concentration and Stable Carbon Isotopic Ratio Analysis}

Methane concentration analyses were performed on board the R/V Hugh R. Sharp using an Agilent 6850 gas chromatograph equipped with a flame ionization detector. From each $\mathrm{CH}_{4}$ concentration vial, $8 \mathrm{ml}$ of headspace gas was drawn out using a syringe, while $8 \mathrm{ml}$ of $\mathrm{CH}_{4}$-free water was injected back in to maintain 
atmospheric pressure. For each analysis, $4 \mathrm{ml}$ of gas was used to flush and fill a $50 \mu \mathrm{l}$ sample loop. This allowed the headspace gas of each vial to be analyzed in duplicate. By switching a two-way Valco valve, the nitrogen carrier gas transferred the contents from the sample loop onto a Gas-Pro capillary column (Length $=15 \mathrm{~m}$, i.d. $=0.32 \mathrm{~mm}$, Agilent). The $\mathrm{GC}$ was kept isothermal at $40{ }^{\circ} \mathrm{C}$ giving $\mathrm{CH}_{4}$ a retention time of 0.80 min. Peak areas recorded by the FID were converted to $\mathrm{CH}_{4}$ concentrations using a four-point calibration generated from a nitrogen blank (AirGas) and $\mathrm{CH}_{4}$ standards with concentrations of 1.01, 10.1, and $100 \mathrm{ppm}$ (AirLiquide). For certain samples where ethane, propane, and butane were analyzed in addition to $\mathrm{CH}_{4}$, the $\mathrm{GC}$ temperature was set to $40{ }^{\circ} \mathrm{C}$ for $2.75 \mathrm{~min}$ before the temperature was increased at $40{ }^{\circ} \mathrm{C} \min ^{-1}$ to $70{ }^{\circ} \mathrm{C}$, where it was held for an additional $1.5 \mathrm{~min}$. The retention times for ethane, propane, and butane were $1.14,2.23$, and $4.35 \mathrm{~min}$, respectively. Since our samples showed no trace of ethane, propane, or butane, the dissolved concentrations of these gases were not calculated. $\mathrm{For}_{\mathrm{CH}}$, dissolved concentrations were calculated by considering the $\mathrm{CH}_{4}$ concentration measured from the headspace, the volumes of the headspace and water in each sample vial, the temperature and salinity of the water sample, and $\mathrm{CH}_{4}$ solubility (Wiesenburg \& Guinasso, 1979). The average standard deviation of duplicate analyses was $2.5 \%$ of the dissolved $\mathrm{CH}_{4}$ concentrations calculated.

Analyses of stable carbon $\mathrm{CH}_{4}$ isotopic values were carried out at the Woods Hole Isotope Laboratories following the same procedures described in Leonte et al. (2017). Briefly, headspace gas was injected into a sample loop and preconcentrated before being transferred onto a capillary column using a helium carrier gas. The gas chromatograph, Agilent 6890 , was heated from -40 to $180{ }^{\circ} \mathrm{C}$ in a stepwise fashion to achieve gas separation. Sample $\mathrm{CH}_{4}$ was oxidized to $\mathrm{CO}_{2}$ using a Finnigan GCCIII combustion interface before isotopic ratio analysis on a Thermo Finnigan Delta ${ }^{\text {Plus }}$ XL. On average, the $1 \sigma$ standard deviation of each measurements was $0.1 \%$.

\subsection{Water Current Velocity Measurements}

Water current velocity was measured by the U.S. Geological Survey using an RDI Workhorse $300 \mathrm{kHz}$ Acoustic Doppler Current Profiler (ADCP) in a deepwater housing which was mounted inside the CTD carousel looking downward. The ADCP was lowered into the water using the CTD carousel, and data were recorded during most CTD deployments and downloaded following each cast. The lowered ADCP (LADCP) data were processed with the Lamont Doherty Earth Observatory software package, version IX_13 (Thurnherr, 2011), using bottom tracking, GPS (from CTD time series), and data from the hull mounted RDI Workhorse $300 \mathrm{kHz}$ ADCP to constrain the inversion model. LADCP processing yielded north and east velocity components that were used to calculate the direction and speed of ocean currents (Ruiz-Angulo et al., 2020). Current velocities were determined at $10 \mathrm{~m}$ depth intervals between $10 \mathrm{~m}$ below the sea surface and the seafloor for all stations and transects except for T4S1, the single station that comprises Transect 7 and the stations on Transect 1. A discussion of the water current velocity data and their relationship to $\mathrm{CH}_{4}$ transport can be found in the supporting information. For this discussion we relied on the LADCP data which spanned the entire water column, rather than the hull mounted ADCP which only measured current velocities to $\sim 100 \mathrm{~m}$ water depth.

\subsection{Fraction of Methane Oxidized}

In a gas seep environment, after $\mathrm{CH}_{4}$ dissolves into a parcel of water, its concentration will decrease due to mixing or microbial oxidation (Mau et al., 2012). However, only microbial oxidation will concurrently shift $\delta^{13} \mathrm{C}_{-} \mathrm{CH}_{4}$ isotopic measurements toward heavier values due to a fractionation effect (Whiticar, 1999). By comparing changes in $\mathrm{CH}_{4}$ concentration with $\delta^{13} \mathrm{C}_{-} \mathrm{CH}_{4}$ isotopic values, the amount of $\mathrm{CH}_{4}$ removed from the water column through oxidation can be calculated. This approach was used by Leonte et al. (2017) using equation (1) to calculate $\boldsymbol{f}_{\boldsymbol{c}}$ or the fraction of $\mathrm{CH}_{4}$ emitted to the water column that has been removed through microbial oxidation.

$$
\boldsymbol{f}_{c}=1-\left(\frac{\delta R+1000}{\delta R_{0}+1000}\right)^{\left(\frac{\alpha_{c}}{1-\alpha_{c}}\right)}
$$

The fraction of $\mathrm{CH}_{4}$ oxidized, $\boldsymbol{f}_{\boldsymbol{c}}$, is calculated based on the difference in $\delta^{13} \mathrm{C}_{-} \mathrm{CH}_{4}$ isotopic values between the time $\mathrm{CH}_{4}$ is initially dissolved into the water column, $\delta \boldsymbol{R}_{\mathbf{0}}$, and a later time when a water sample is 
collected, $\delta \boldsymbol{R}$, along with the fractionation factor, $\boldsymbol{\alpha}_{\boldsymbol{c}}$, which is a constant characterizing the magnitude of isotopic fractionation as $\mathrm{CH}_{4}$ oxidation progresses. If the source of $\mathrm{CH}_{4}$ to the water column is a gas seep, $\delta \boldsymbol{R}_{\mathbf{0}}$ represents the isotopic value of $\mathrm{CH}_{4}$ when it dissolves from the gas into the liquid phase. If in situ methanogenesis is the $\mathrm{CH}_{4}$ source, $\delta \boldsymbol{R}_{\mathbf{0}}$ is the isotopic value of $\mathrm{CH}_{4}$ when it is initially generated by microbes but before fractionation through microbial oxidation. This model assumes that only oxidation affects $\delta^{13} \mathrm{C}_{-} \mathrm{CH}_{4}$ isotopic values within a water parcel as it is carried by ocean currents. A fractionation factor of $\alpha_{c}=1.0115$ was determined by Leonte et al. (2017) in Hudson Canyon, which also lies along the USAM, and was used for the calculations presented here since that study and this current one consider similar geographical and biogeochemical environments. In the Hudson Canyon, the dominant water column $\mathrm{CH}_{4} \operatorname{sink}$ was microbial oxidation as opposed to mixing with neighboring waters, fitting the conditions of a closed system, and allowing for $\alpha_{c}$ to be calculated based on $\mathrm{CH}_{4}$ concentration and $\delta^{13} \mathrm{C}_{-} \mathrm{CH}_{4}$ measurements (Leonte et al., 2017).

\section{Results}

\subsection{Gas Bubble Identification}

The Simrad EK80 echosounder was used to detect water column gas bubbles and to determine whether the CTD carousel was within a bubble plume during water sampling (Baldwin et al., 2020). This allowed us to determine if the water samples collected were directly influenced by gas bubble emissions and thus constrain the isotopic signature of $\mathrm{CH}_{4}$ emitted from gas seeps. Figure 2 shows images generated by the echosounder as water samples were collected at T1S2 and T4S3, highlighting strong near-seafloor water column backscatter associated with gas bubbles at T1S2 and no such signal at T4S3. The echosounder data also revealed strong water column backscatter for T1S1 through T1S4 and less intense backscatter at T2S3 and T5S2. It should be noted that the echosounder record collapses onto a flat display all detections within a conical ensonification area beneath the EK80 transducer, and the ensonification cone is larger for greater water depths. In some cases, the CTD carousel appeared to be within a backscatter cloud associated with a bubble plume, yet elevated $\mathrm{CH}_{4}$ was not detected in the water samples. For example, the echosounder imaged strong near-seafloor backscatter at T5S2, but the water samples collected within the apparent bubble flare had $\mathrm{CH}_{4}$ concentrations below $4 \mathrm{nM}$. This apparent contradiction could reflect the highly localized nature of fluctuations in $\mathrm{CH}_{4}$ concentrations near the seafloor. Alternately, the enhanced backscatter imaged by the echosounder could represent bioscatters like krill instead of $\mathrm{CH}_{4}$ bubbles.

\subsection{Methane Concentration and Isotopic Distributions}

Dissolved $\mathrm{CH}_{4}$ concentrations along the MAB varied based on depth and location and spanned several orders of magnitude from $1.3 \mathrm{nM}$ to $2.1 \mu \mathrm{M}$ (Leonte et al., 2020). Nearly all samples were supersaturated with $\mathrm{CH}_{4}$ compared to the atmosphere; average $\mathrm{CH}_{4}$ concentrations measured near the surface were $4.6 \pm 0.2 \mathrm{nM}$ which is slightly greater compared to atmospheric equilibrium $(\sim 2.1 \mathrm{nM})$. Samples considered "near the surface" were those collected at a depth of $10 \mathrm{~m}$ or shallower since water density was usually uniform over this depth horizon. At most stations, $\mathrm{CH}_{4}$ concentrations were lower at the surface than at greater depths, but the highest $\mathrm{CH}_{4}$ concentrations were not necessarily measured at the seafloor. For example, at Transect 2 the highest $\mathrm{CH}_{4}$ concentrations were consistently measured at $400 \mathrm{~m}$ depth, which was up to several hundred meters shallower than the seafloor based on the station (Figure 3a).

Stable isotopic values of $\delta^{13} \mathrm{C}_{-} \mathrm{CH}_{4}$ were variable within the water column, ranging from $-70.2 \%$ o to $-14.9 \%$ o (Leonte et al., 2020). Similar to the $\mathrm{CH}_{4}$ concentration measurements, $\delta^{13} \mathrm{C}-\mathrm{CH}_{4}$ isotopic values did not have a straightforward relationship with depth, which was likely due to the different $\mathrm{CH}_{4}$ sources and sinks active in the water column. Lighter, or more negative, $\delta^{13} \mathrm{C}-\mathrm{CH}_{4}$ isotopic values were measured in the subsurface where aerobic in situ $\mathrm{CH}_{4}$ production was likely or at stations located close to seafloor gas seeps which also contributed $\mathrm{CH}_{4}$ to the water column. The lightest isotopic values were measured directly overlying gas seeps. At stations farther than $2.5 \mathrm{~km}$ from gas seeps, isotope distributions were highly heterogeneous with large gradients in isotopic values over relatively short depth intervals. Near the surface $(0-10 \mathrm{~m}), \delta^{13} \mathrm{C}-\mathrm{CH}_{4}$ isotopic values were close to atmospheric values at $\sim-47 \%$, suggesting near equilibrium between the sea surface and the atmosphere (Schaefer et al., 2016). 


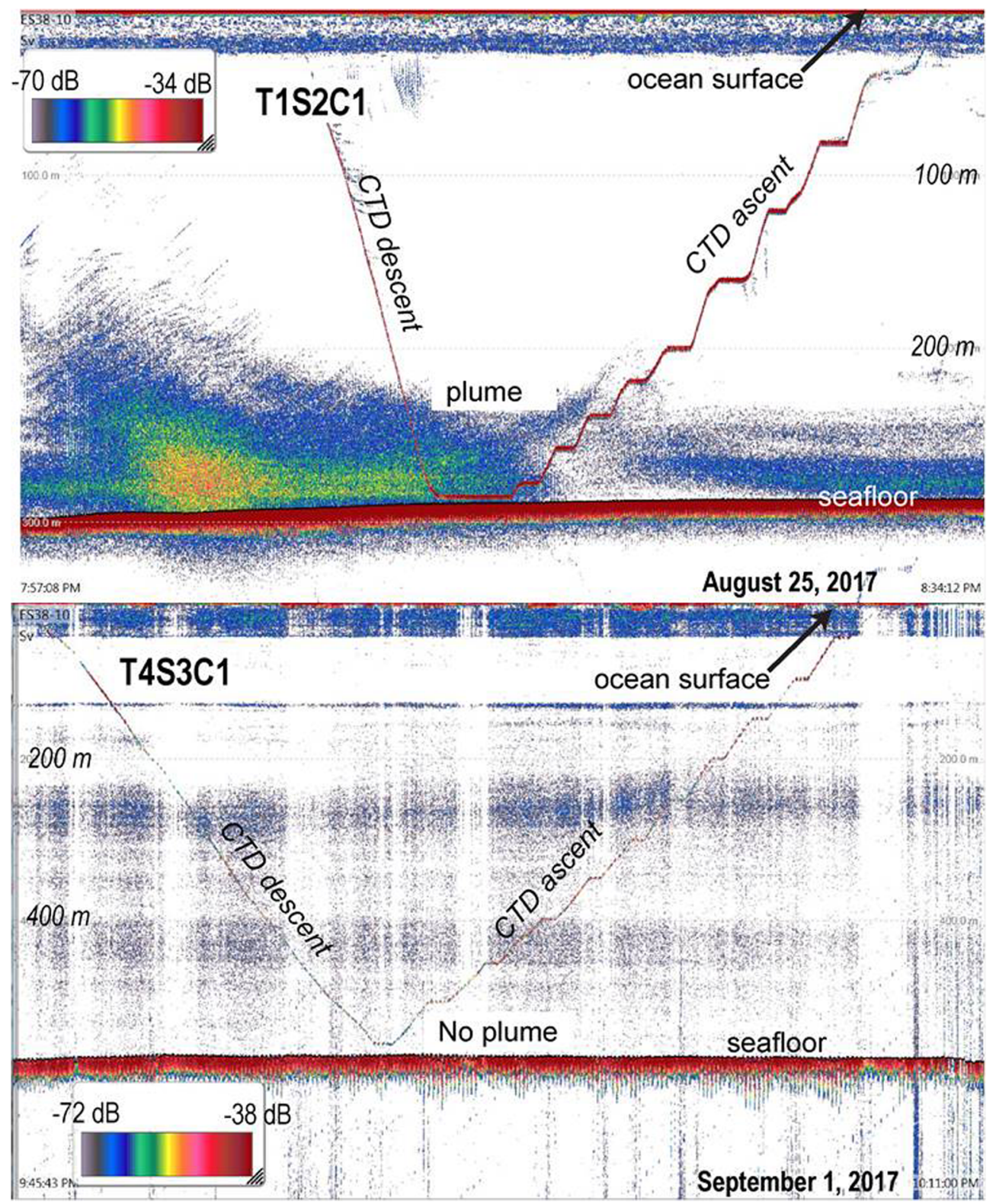

Figure 2. Acoustic echosounder images recorded at two sampling stations. The $x$ axis represents time, while the colored dots represent acoustic backscatter within the water column recorded by the echosounder. This may include suspended particles, gas bubbles, or the Niskin bottle carousel (red line). The top panel shows the image recorded at Transect 1, Station 2, CTD Cast 1 (T1S2) where intense backscatter near the seafloor is indicative of gas bubbles, while the bottom panel was recorded at Transect 4, Station 3, CTD Cast 1 (T4S3) where sparse backscatter suggests that no bubbles were present.

\section{Discussion}

\subsection{Methane Sources}

Along the $\mathrm{MAB}, \mathrm{CH}_{4}$ sources in the water column include seafloor gas seeps, in situ aerobic production, and the atmosphere. At most sampling stations, we observed at least one $\mathrm{CH}_{4}$ concentration maxima occurring roughly between 100 and $200 \mathrm{~m}$ depths (Figure $3 \mathrm{~b}$ ). This feature is consistent with previous studies presenting vertical $\mathrm{CH}_{4}$ concentration profiles in open ocean environments (Holmes et al., 2000; Reeburgh, 2007). While gas seeps have been identified along the MAB originating at depths as shallow as $53 \mathrm{~m}$, this subsurface $\mathrm{CH}_{4}$ maximum persisted even where seeps were not present at these depths (e.g., Transects 4, 6, and 7). The 
(a) - Transect 2
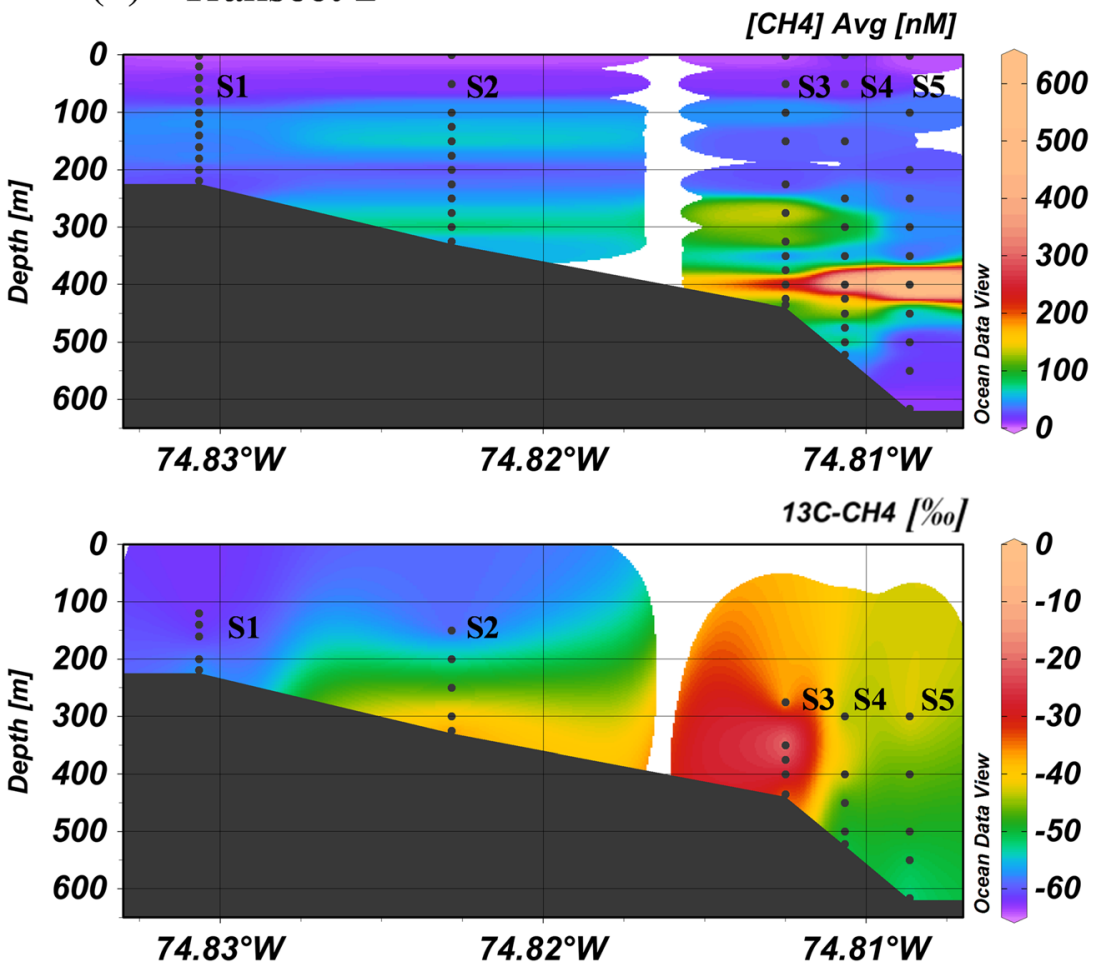

(b) - Transect 4
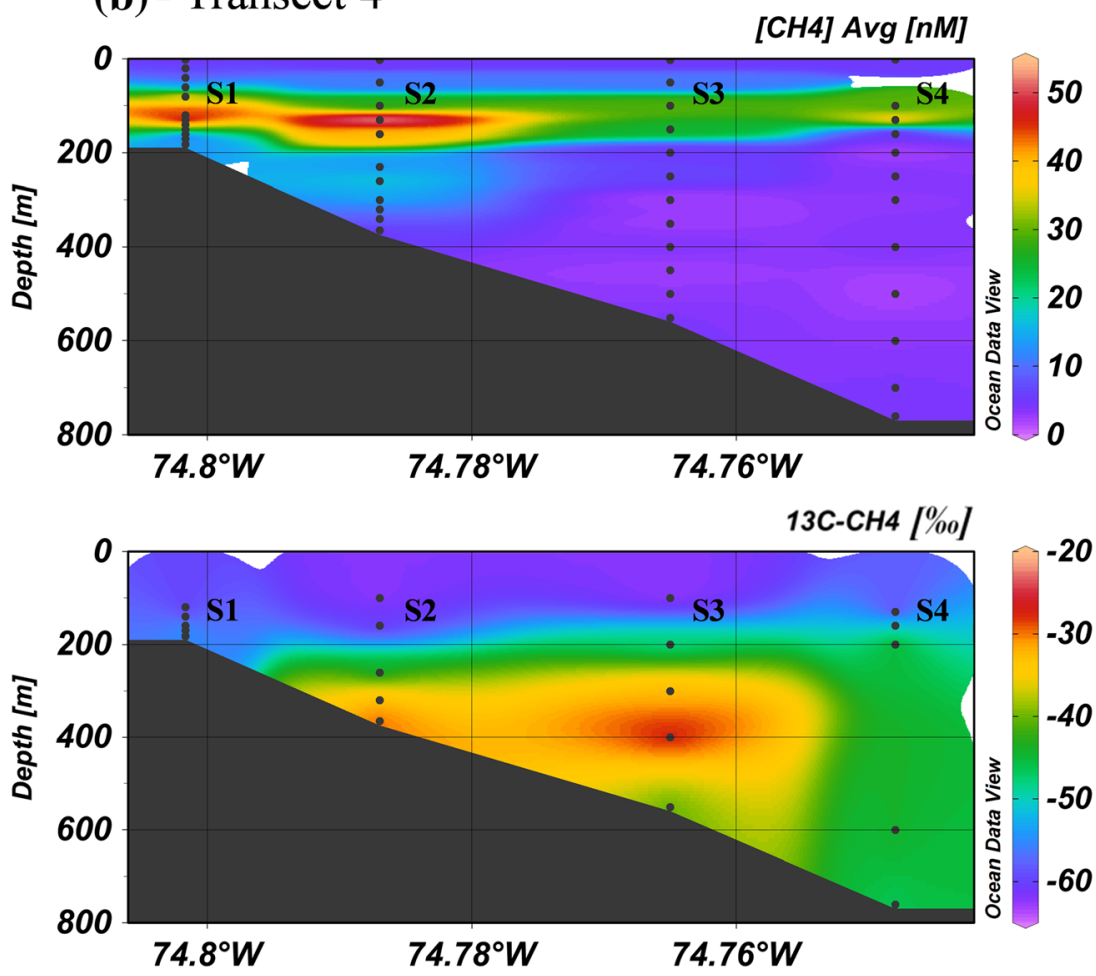

Figure 3. Interpolated $\mathrm{CH}_{4}$ concentration and $\delta^{13} \mathrm{C}_{-} \mathrm{CH}_{4}$ measurements for two sampling transects along the MAB. The station numbers within Transect 2 (a) and Transect 4 (b) are indicated, and black dots show where specific water samples were collected. Note the different scale ranges for the different concentration and isotope plots. Measured data were interpolated using Ocean Data View. Although Transects 2 and 4 are only 30 km apart, they show different $\mathrm{CH}_{4}$ concentration and $\delta^{13} \mathrm{C}-\mathrm{CH}_{4}$ distributions. 
nearest gas seep was identified at a distance of 4.4, 8.3, and $2.5 \mathrm{~km}$ away from Transects 4, 6, and 7, respectively, based on data collected by Baldwin et al. (2020) and Skarke et al. (2014). At these transects, $\mathrm{CH}_{4}$ concentrations measured in the subsurface were not only elevated above background levels but also consistently larger than measurements from the deeper water column. For example, Figure $3 \mathrm{~b}$ shows an interpolation of $\mathrm{CH}_{4}$ concentration and $\delta^{13} \mathrm{C}-\mathrm{CH}_{4}$ isotope measurements from Transect 4 . The highest $\mathrm{CH}_{4}$ concentrations were centered on $100 \mathrm{~m}$ for all stations, and although a cluster of seeps was identified to the south of Transect 4, these seeps originate at depths of 211-494 m (Skarke et al., 2014), well below the observed $\mathrm{CH}_{4}$ maximum.

Figure 4 shows a plot of $\delta^{13} \mathrm{C}-\mathrm{CH}_{4}$ isotopic values against $\mathrm{CH}_{4}$ concentrations for samples collected at depths shallower than $200 \mathrm{~m}$. This plot differentiates between samples that were collected near known gas seeps (Transects 1, 2, 3, and 5) and samples that were not (Transects 4, 6, and 7). Transects identified as being near gas seeps were within $2.5 \mathrm{~km}$ of a gas seep identified in the data collected here, Baldwin et al. (2020), or reported in Skarke et al. (2014). Where gas seeps were present, $\mathrm{CH}_{4}$ concentrations were larger, ranging from 17 to $139 \mathrm{nM}$, while samples without gas seep influence had concentrations ranging from 3 to $55 \mathrm{nM}$. For transects without nearby gas seeps, $\mathrm{CH}_{4}$ concentrations decrease below $200 \mathrm{~m}$ depth, suggesting that aerobic methanogenesis is not active below this depth or that the sink of $\mathrm{CH}_{4}$ oxidation is outcompeting this $\mathrm{CH}_{4}$ source. However, for transects within $2.5 \mathrm{~km}$ of identified seafloor gas seeps, elevated $\mathrm{CH}_{4}$ concentrations were observed at multiple depths throughout the water column. For example, multiple clusters of gas seeps have been identified close to Transect 1 where high $\mathrm{CH}_{4}$ concentrations were recorded near the seafloor at multiple stations. This suggests that below $200 \mathrm{~m}$ depth, gas seeps are the dominant source of $\mathrm{CH}_{4}$ to the water column.

In order to constrain the isotopic signature of $\mathrm{CH}_{4}$ produced through aerobic methanogenesis in subsurface waters, we examined $\delta^{13} \mathrm{C}-\mathrm{CH}_{4}$ measurements of samples collected in the subsurface, at depths shallower than $200 \mathrm{~m}$, that were not influenced by nearby gas seeps (Figure 4). Within this subset of data, the sample with the highest $\mathrm{CH}_{4}$ concentration also had the lightest $\delta^{13} \mathrm{C}_{-} \mathrm{CH}_{4}$ value, $-65.1 \%$, which we assume represents the isotopic signature of $\mathrm{CH}_{4}$ produced aerobically in this region.

In order to determine whether seafloor gas seeps directly influence $\mathrm{CH}_{4}$ concentrations at the surface, it is important to constrain the vertical distance over which gas bubbles provide a source of $\mathrm{CH}_{4}$ to the water column. This quantity depends largely on the seafloor depth of bubble release, the chemical composition inside and outside the bubble, and the diameter of gas bubbles when emitted at the seafloor. The Texas A\&M Oilspill Calculator was designed to calculate the flux of $\mathrm{CH}_{4}$ to the water column during bubble ascent (Leonte et al., 2018; McGinnis et al., 2006; Socolofsky et al., 2015; Wang et al., 2016). To date, the only measurements of gas bubble diameter along the MAB were reported by Skarke et al. (2014); using ROV video footage, bubble diameters of 2.3-3.2 and 3.1-4.2 mm were measured at two distinct gas seeps. Based on these measurements, the Texas A\&M Oilspill Calculator model shows that bubbles originating at the seafloor with diameters of 2, 3 and $4 \mathrm{~mm}$ lose over $90 \%$ of their starting $\mathrm{CH}_{4}$ as they ascend to 55, 105, and $150 \mathrm{~m}$ above the seafloor, respectively. This means that gas seeps only have the potential to directly increase water column $\mathrm{CH}_{4}$ concentrations over these depth horizons and that gas seeps that originate at seafloor depths greater than $150 \mathrm{~m}$ are unlikely to increase surface $\mathrm{CH}_{4}$ concentrations via bubble transport. Once gas bubble $\mathrm{CH}_{4}$ dissolves into the water column, it is carried by water currents along isopycnal surfaces. Given the close relationship between water density and depth among our transects (Figure S3), a dissolved $\mathrm{CH}_{4}$ plume derived from a gas seep should remain at a similar depth while being transported by ocean currents. As seep derived $\mathrm{CH}_{4}$ is transported, $\mathrm{CH}_{4}$ sinks such as microbial oxidation and dilution with background waters actively reduce $\mathrm{CH}_{4}$ concentrations (Mau et al., 2012). Since deeper waters have a longer transit time to reach the surface, it is more likely that $\mathrm{CH}_{4}$ emitted from shallower seeps will influence sea surface $\mathrm{CH}_{4}$ concentrations.

Measurements of $\delta^{13} \mathrm{C}-\mathrm{CH}_{4}$ isotopes have previously been used to identify the mechanism responsible for generating $\mathrm{CH}_{4}$ (Whiticar, 1999). Both microbial and thermogenic processes can convert organic matter to $\mathrm{CH}_{4}$, but these two pathways produce $\mathrm{CH}_{4}$ with divergent isotopic signatures. Generally speaking, microbial production tends to generate $\mathrm{CH}_{4}$ with isotopic values between $-80 \%$ ond $-50 \%$, while thermogenic production leads to $\mathrm{CH}_{4}$ isotopic values between $-50 \%$ and $-20 \%$ (Whiticar, 1999). The data measured here 


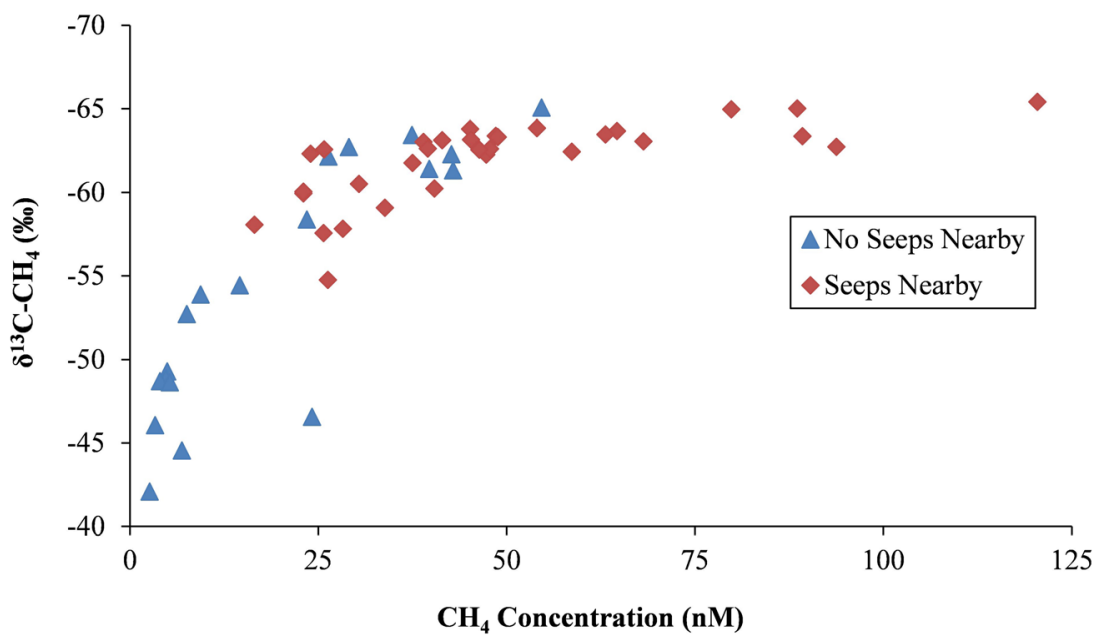

Figure 4. Plot of $\mathrm{CH}_{4}$ concentration versus $\delta^{13} \mathrm{C}_{-} \mathrm{CH}_{4}$ from samples collected in the subsurface or depths of $10-200 \mathrm{~m}$ along the MAB. Data are split up between stations without nearby gas seeps, blue triangles, and stations influenced by seafloor gas seeps, red diamonds. Stations designated to not be influenced by gas seeps were at least $2.5 \mathrm{~km}$ from the nearest identified gas seep using data collected here, Baldwin et al. (2020), and reported in Skarke et al. (2014). The higher $\mathrm{CH}_{4}$ concentrations measured at stations closer than $2.5 \mathrm{~km}$ to identified gas seeps suggest that both aerobic production and gas seeps were supplying $\mathrm{CH}_{4}$ to subsurface waters.

varied through these microbial and thermogenic ranges, but most of these samples were heavily influenced by aerobic $\mathrm{CH}_{4}$ oxidation in the water column, which shifts the $\delta^{13} \mathrm{C}_{-} \mathrm{CH}_{4}$ toward heavier (apparently thermogenic) values. Thus, in order to determine if $\mathrm{CH}_{4}$ was produced microbially or thermogenically, we had to identify $\delta^{13} \mathrm{C}_{-}-\mathrm{CH}_{4}$ values that were least likely to be influenced by oxidation (labeled here as $\delta \boldsymbol{R}_{\mathbf{0}}$ ). Estimates of the isotopic signature of gas seep $\mathrm{CH}_{4}$ are more robust if they are based on $\delta^{13} \mathrm{C}_{-}-\mathrm{CH}_{4}$ measurements from samples collected on top of, or close to, gas seeps with a high bubble abundance. In these environments, the high flux of $\mathrm{CH}_{4}$ would overwhelm any potential shift in isotopic values due to mixing with nearby waters or oxidation. Stations at Transect 1 showed the greatest abundance of bubbles identified by the echosounder, and $\delta^{13} \mathrm{C}_{-} \mathrm{CH}_{4}$ isotopic values measured on samples collected near this seafloor source ranged from $-70.2 \%$ o to $-62.0 \%$. Among these, the sample with the lightest $\delta^{13} \mathrm{C}_{-} \mathrm{CH}_{4}$ value, $-70.2 \%$, and highest $\mathrm{CH}_{4}$ concentration, $2.1 \mu \mathrm{M}$, was collected at Transect 1 , Station 3. Due to these conditions, $\delta \boldsymbol{R}_{\mathbf{0}}$ is likely close to $-70.2 \%$ for the gas seeps located near Transect 1 .

At Transect 2 the highest $\mathrm{CH}_{4}$ concentrations were all measured at a depth of $400 \mathrm{~m}$ for Stations 3, 4, and 5 . Although our echosounder readings did not detect a large abundance of water column bubbles at these stations, previous studies have identified a number of gas seeps near Transect 2, which could act as the dominant source of $\mathrm{CH}_{4}$ at $400 \mathrm{~m}$ depth (Skarke et al., 2014). A Keeling plot was constructed to estimate the $\delta^{13} \mathrm{C}_{-} \mathrm{CH}_{4}$ of $\mathrm{CH}_{4}$ emitted from gas seeps near Transect 2 (Figure 5). A Keeling plot can be used to estimate the isotopic signature of a given source term by calculating the linear least squares regression when plotting measurements of $\delta^{13} \mathrm{C}_{-} \mathrm{CH}_{4}$ versus the inverse of $\mathrm{CH}_{4}$ concentration (Keeling, 1958). The $y$ intercept represents the $\delta^{13} \mathrm{C}_{-} \mathrm{CH}_{4}$ signature when the concentration of $\mathrm{CH}_{4}$ from this source is infinite compared to the background. For our calculation, we used a geometric mean regression, rather than a least squares regression, to take into account errors in both the $x$ and $y$ variables used in the Keeling plot (Pataki et al., 2003). This approach suggests that the $\delta^{13} \mathrm{C}_{-} \mathrm{CH}_{4}$ of $\mathrm{CH}_{4}$ emitted from gas seeps near Transect 2 was $-53.4 \%$. Although certain measurements from Transect 2 outside of the concentration plume at $400 \mathrm{~m}$ had lighter $\delta^{13} \mathrm{C}_{-} \mathrm{CH}_{4}$ isotopic values than the samples used to construct the Keeling plot, they also had lower $\mathrm{CH}_{4}$ concentrations, suggesting that $\mathrm{CH}_{4}$ was derived from a different source compared to the $\mathrm{CH}_{4}$ plume identified at $400 \mathrm{~m}$. The $\delta \boldsymbol{R}_{\mathbf{0}}$ value of $-53.4 \%$ implies that seeps in this region emit $\mathrm{CH}_{4}$ with a heavier $\delta^{13} \mathrm{C}-\mathrm{CH}_{4}$ value than the seeps identified at Transect 1 . However, based on the Geometric Mean regression calculation, this $\delta \boldsymbol{R}_{\mathbf{0}}$ value had an uncertainty of $7.2 \%$ o due to the low sample size $(n=3)$ and variability of the data (Figure 5). Given the available data presented here, the value of $\delta^{13} \mathrm{C}-\mathrm{CH}_{4}$ emitted from seafloor seeps along the MAB, $\delta \boldsymbol{R}_{\mathbf{0}}$, was assumed to be within the range of $-70.2 \%$ ond $-53.4 \%$. 


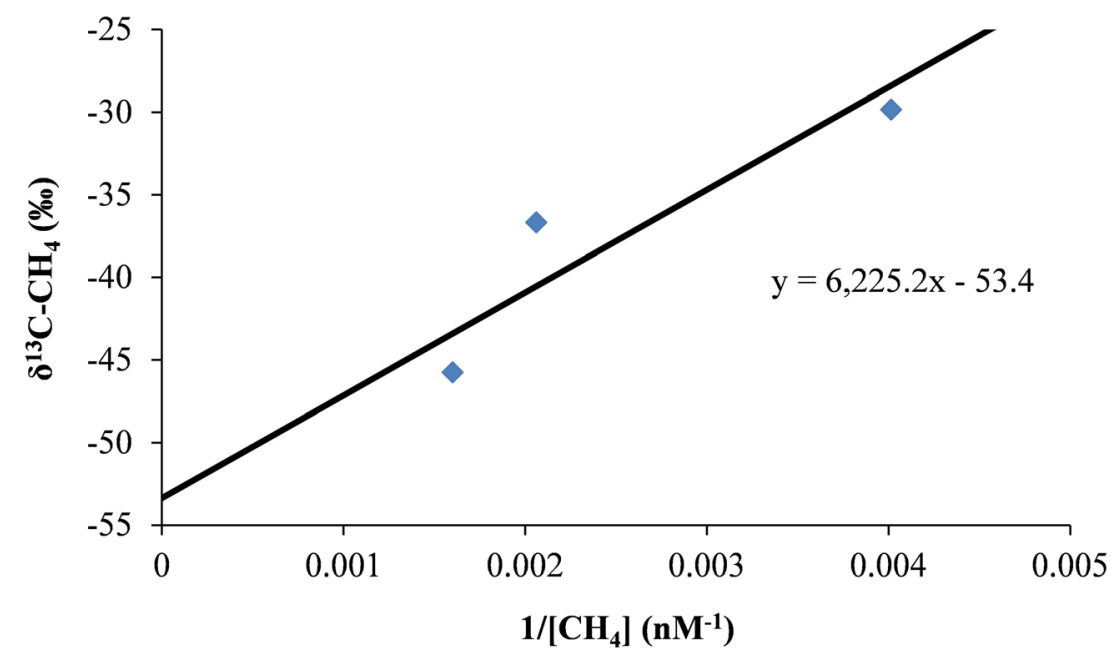

Figure 5. Keeling plot generated to determine the $\delta^{13} \mathrm{C}_{-} \mathrm{CH}_{4}$ signature of $\mathrm{CH}_{4}$ emitted from gas seeps. The Keeling plot was generated using $\mathrm{CH}_{4}$ concentration and $\delta^{13} \mathrm{C}_{-} \mathrm{CH}_{4}$ isotopic values measured at $400 \mathrm{~m}$ depth in Transect 2. Using a geometric mean regression, the $y$ intercept, and thus the isotopic signature of $\mathrm{CH}_{4}$ emitted from gas seeps at this location, was $-53.4 \pm 7.2 \%$.

Based on the isotopic values of $\mathrm{CH}_{4}$ emitted from gas seeps determined here $\left(-70.2 \%\right.$ to $-53.4 \%$ ), this $\mathrm{CH}_{4}$ is likely produced through microbial processes. This is consistent with a previous study investigating the $\delta^{13} \mathrm{C}$ signature of autogenic carbonates formed near gas seeps along the MAB (Prouty et al., 2016). In the subsurface, where water depth was shallower than $200 \mathrm{~m}$, measurements of $\delta^{13} \mathrm{C}_{-} \mathrm{CH}_{4}$ ranged between $-65.4 \%$ o and $-42.1 \%$, suggesting that the $\mathrm{CH}_{4}$ source in the subsurface is also of microbial origin. Although some samples collected shallower than $200 \mathrm{~m}$ depth have $\delta^{13} \mathrm{C}_{-} \mathrm{CH}_{4}$ signatures heavier than the typical microbial production cutoff of $-50 \%$, it is likely that when this $\mathrm{CH}_{4}$ was produced, the ${ }^{13} \mathrm{C}_{-} \mathrm{CH}_{4}$ values were within the microbial range and were later altered through microbial oxidation to a heavier value, as is evidenced by the concurrent shifts to lower dissolved concentrations (Figure 4). Thermogenic production, unlike microbial production, would also lead to the formation of longer chained hydrocarbons such as ethane, propane, and butane. Several water samples collected at Transect 5 were analyzed for these compounds, and all were below detection limits.

\subsection{Methane Oxidation}

Microbial oxidation of $\mathrm{CH}_{4}$ readily occurs in oxygenated waters, making this process an important sink of oceanic $\mathrm{CH}_{4}$ (Chan et al., 2019; Reeburgh, 2007). Previous work in the Hudson Canyon showed that $\mathrm{CH}_{4}$ emitted from seafloor seeps is quickly and quantitatively oxidized (Leonte et al., 2017). However, the unique topography and water circulation patterns in Hudson Canyon likely helped enhance the rate of $\mathrm{CH}_{4}$ oxidation by trapping $\mathrm{CH}_{4}$ and methanotroph-laden waters within the canyon walls.

Similarly, samples collected here in other regions of the MAB have a wide range of $\delta^{13} \mathrm{C}^{-} \mathrm{CH}_{4}$ values, driven partially by varying isotopic signatures of $\mathrm{CH}_{4}$ sources (see previous section) and mostly by the microbial oxidation of $\mathrm{CH}_{4}$. At nearly all transects, $\delta^{13} \mathrm{C}_{-} \mathrm{CH}_{4}$ isotopic values heavier than $-30 \%$ have been measured, which is significantly heavier than the $\delta^{13} \mathrm{C}^{-} \mathrm{CH}_{4}$ of $\mathrm{CH}_{4}$ entering the water column from gas seeps $\left(-70.2 \%\right.$ to $-53.4 \%$ ) or produced by aerobic methanogenesis $(-65.1 \%)$. Samples with $\delta^{13} \mathrm{C}_{-} \mathrm{CH}_{4}$ isotopic values heavier than $-53.4 \%$ have likely been influence by microbial oxidation since this process progressively enriches the $\mathrm{CH}_{4}$ pool within a parcel of water with the heavier isotopologue, ${ }^{13} \mathrm{CH}_{4}$. For deep water column samples, collected below $200 \mathrm{~m}$, where gas seeps are the dominant $\mathrm{CH}_{4}$ source, the fraction of $\mathrm{CH}_{4}$ oxidized, $\boldsymbol{f}_{\boldsymbol{c}}$, was calculated using equation (1) based on $\delta^{13} \mathrm{C}_{-} \mathrm{CH}_{4}$ measurements of $\mathrm{CH}_{4}$ entering the water column, $\delta \boldsymbol{R}_{\mathbf{0}}\left(-70.2 \%\right.$ to $-53.4 \%$ ) and $\delta^{13} \mathrm{C}^{-} \mathrm{CH}_{4}$ measurements of water samples influenced by oxidation, $\delta \boldsymbol{R}$. Since we determined a range of values for $\delta \boldsymbol{R}_{\boldsymbol{0}}$, the resulting calculations of $\boldsymbol{f}_{\boldsymbol{c}}$ using equation (1) also produced a range of values. We calculated the maximum value of $\boldsymbol{f}_{\boldsymbol{c}}$ when $\delta \boldsymbol{R}_{\mathbf{0}}$ was set to $-70.2 \%$ and the minimum value of $\boldsymbol{f}_{\boldsymbol{c}}$ when $\delta \boldsymbol{R}_{\mathbf{0}}$ was set to $-53.4 \%$ (Leonte et al., 2020). For $\delta \boldsymbol{R}$ measurements lighter than 


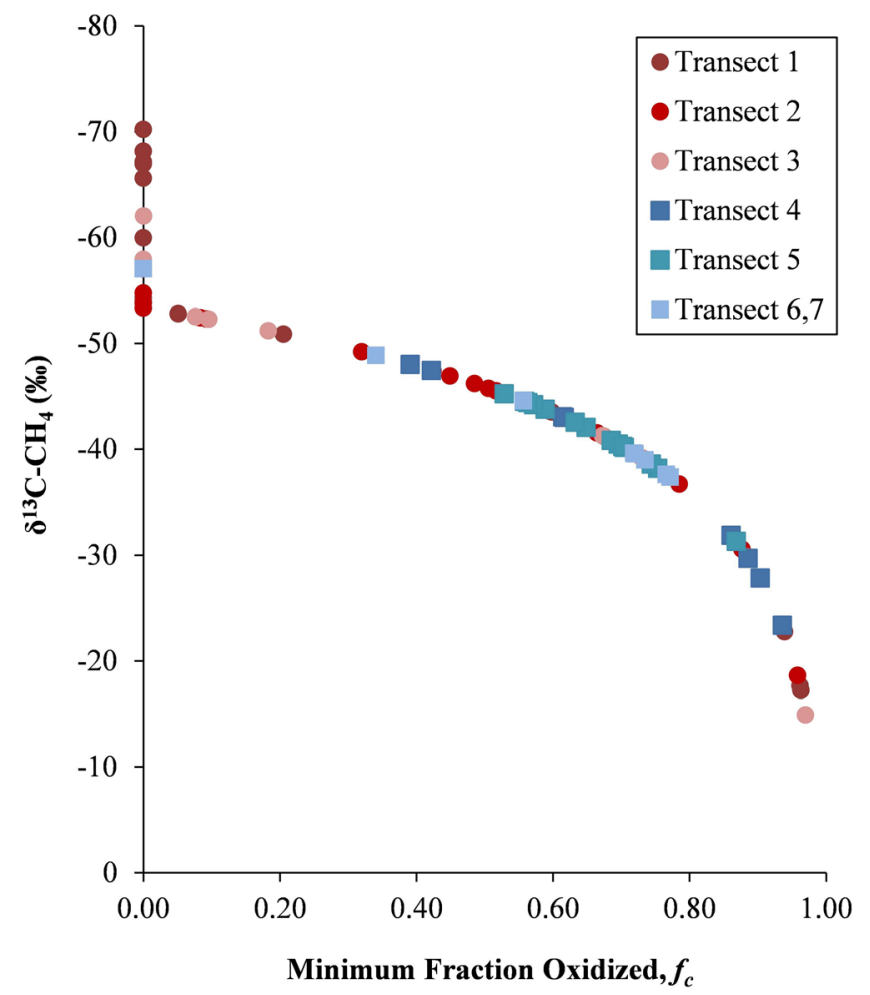

Figure 6. Plot of the minimum $\mathrm{CH}_{4}$ fraction oxidized, $f_{c}$, against $\delta^{13} \mathrm{C}_{-} \mathrm{CH}_{4}$ for samples collected along the MAB below $200 \mathrm{~m}$. Circles show transects close to gas seeps (within $2.5 \mathrm{~km}$ ) and likely receiving significant $\mathrm{CH}_{4}$ inputs, while squares show transects farther than $2.5 \mathrm{~km}$ from gas seeps.
$-53.4 \%$, the minimum $\boldsymbol{f}_{\boldsymbol{c}}$ value calculated was negative and thus set to 0 . This situation implies that at a minimum, no oxidation had occurred at the time of sampling after seep-derived $\mathrm{CH}_{4}$ dissolved into the water column.

Calculated $\boldsymbol{f}_{\boldsymbol{c}}$ values show that $\mathrm{CH}_{4}$ oxidation is an active process which has affected many of these samples to a large degree. Of the 75 samples collected from the deeper water column, below $200 \mathrm{~m}$, and measured for $\mathrm{CH}_{4}$ isotopic ratios, 7 had a minimum $\boldsymbol{f}_{\boldsymbol{c}}$ value greater than 0.9 and 28, 47, and 54 samples had minimum $\boldsymbol{f}_{\boldsymbol{c}}$ values greater than $0.7,0.5$ and 0.3 , respectively (Leonte et al., 2020). On the other hand, maximum $\boldsymbol{f}_{\boldsymbol{c}}$ values suggest that 47 samples have over $90 \%$ of $\mathrm{CH}_{4}$ removed through oxidation. The distribution of $\delta \boldsymbol{R}$ and $\boldsymbol{f}_{\boldsymbol{c}}$ values was also correlated to the presence or absence of nearby gas seeps. Figure 6 shows a plot of the minimum $\mathrm{CH}_{4}$ fraction oxidized, $\boldsymbol{f}_{\boldsymbol{c}}$, against $\delta^{13} \mathrm{C}-\mathrm{CH}_{4}$ isotopic values of samples collected from the deeper water column. Transects 1, 2, and 3, located close to gas seep clusters, showed an abundance of samples with $\boldsymbol{f}_{\boldsymbol{c}}$ values as low as 0 due to significant $\mathrm{CH}_{4}$ inputs from nearby seeps. However, samples from these transects also had a number of samples with $\boldsymbol{f}_{\boldsymbol{c}}$ values close to 1 indicating a strong microbial oxidation signal despite the influence of gas seeps. For Transects $4,5,6$, and $7, \boldsymbol{f}_{\boldsymbol{c}}$ values had a narrower range that was also shifted toward larger values of $\boldsymbol{f}_{\boldsymbol{c}}$ due to a lack of active $\mathrm{CH}_{4}$ inputs.

Water column data collected within the subsurface also indicate a strong microbial oxidation sink. Figure 4 shows a plot of $\mathrm{CH}_{4}$ concentration and $\delta^{13} \mathrm{C}_{-} \mathrm{CH}_{4}$ measurements consistent with the expected trend produced through microbial oxidation: Lower $\mathrm{CH}_{4}$ concentrations correlate with heavier $\delta^{13} \mathrm{C}_{-} \mathrm{CH}_{4}$ values as oxidation progresses. As mentioned above, dividing the shallow water column samples based on the influence of nearby gas seeps results in different patterns regarding $\mathrm{CH}_{4}$ concentration and $\delta^{13} \mathrm{C}_{-} \mathrm{CH}_{4}$ measurements. Since $\delta^{13} \mathrm{C}-\mathrm{CH}_{4}$ values for samples affected by gas seeps within the subsurface $\left(-65.4 \%\right.$ o to $-54.8 \%$ o) are within the same range as $\mathrm{CH}_{4}$ emitted from gas seeps within the deeper water column $(-70.2 \%$ o to $-53.4 \%$ ), it is possible that this isotopic variation is entirely driven by the differences in $\mathrm{CH}_{4}$ isotopes emitted from gas seeps. When calculating the fraction oxidized using a $\delta \boldsymbol{R}_{\mathbf{0}}$ value range of $-70.2 \%$ o to $-53.4 \%$, the minimum $\boldsymbol{f}_{\boldsymbol{c}}$ value for these samples was 0 while the maximum $\boldsymbol{f}_{\boldsymbol{c}}$ value ranged from 0.37 to 0.91 (Leonte et al., 2020). For samples in the subsurface that were collected farther than $2.5 \mathrm{~km}$ from the nearest gas seep, the sample with the highest $\mathrm{CH}_{4}$ concentration also had the lightest isotopic signature $(-65.1 \%$ ), which we assume represents the isotopic signature for in situ methanogenesis. Assuming $\delta \boldsymbol{R}_{\mathbf{0}}=-65.1 \%$, $\boldsymbol{f}_{\boldsymbol{c}}$ was calculated based on equation (1). Values of $\boldsymbol{f}_{\boldsymbol{c}}$ ranged from 0 to 0.88 , implying a strong microbial oxidation sink (Leonte et al., 2020). However, equation (1) assumes that no additional $\mathrm{CH}_{4}$ is added to a water parcel after the initial start of the oxidation reaction. Since in situ methanogenesis likely provides a semicontinuous flux of $\mathrm{CH}_{4}$ to the water column, the quantity of $\mathrm{CH}_{4}$ oxidized is likely underestimated using equation (1). Despite the $\mathrm{CH}_{4}$ maximum observed between 100 and $200 \mathrm{~m}$ water depths, dissolved $\mathrm{CH}_{4}$ concentrations quickly decreased to values near atmospheric equilibrium closer to the sea surface. This suggests that $\mathrm{CH}_{4}$ oxidation is a thorough and near-complete removal mechanism of dissolved $\mathrm{CH}_{4}$ despite widespread gas seepage and aerobic methanogenesis along the MAB.

\section{Conclusions}

When assessing the contribution of $\mathrm{CH}_{4}$ to surface waters from various sources along the MAB, depth was found to be a key variable. Within the subsurface between 100 and $200 \mathrm{~m}$ depths, in situ production was responsible for elevating $\mathrm{CH}_{4}$ concentrations above background at nearly all stations, with shallow gas seeps providing an additional $\mathrm{CH}_{4}$ source at these depths. In the deeper water column, depths greater than $200 \mathrm{~m}$, gas seeps appeared to be the dominant source of $\mathrm{CH}_{4}$. Measurements of $\delta^{13} \mathrm{C}_{-} \mathrm{CH}_{4}$ suggest that the $\mathrm{CH}_{4}$ 
emitted from the sampled gas seeps is produced through microbial rather than thermogenic processes; however, more seep gas sampling on the MAB continental slope will be needed to confirm the variation and spatial distribution of this $\mathrm{CH}_{4}$ source. In this study, dissolved $\delta^{13} \mathrm{C}_{-} \mathrm{CH}_{4}$ measurements were used to constrain the fraction of $\mathrm{CH}_{4}$ oxidized in the water column, $\boldsymbol{f}_{\boldsymbol{c}}$. Despite variations in the $\mathrm{CH}_{4}$ isotopes at the point of release into the water column, estimates of $\boldsymbol{f}_{\boldsymbol{c}}$ still display substantial $\mathrm{CH}_{4}$ oxidation.

As water currents carry waters laden with $\mathrm{CH}_{4}$, dilution and microbial oxidation act to reduce $\mathrm{CH}_{4}$ concentrations, sometimes down to background levels. The determination of $\boldsymbol{f}_{\boldsymbol{c}}$ using equation (1) is based on a closed system Rayleigh model. This model, which takes a closed system Lagrangian approach, assumes that only microbial oxidation is responsible for reducing $\mathrm{CH}_{4}$ concentration and altering $\delta^{13} \mathrm{C}_{-} \mathrm{CH}_{4}$ measurements. As the water parcel travels away from the seep, oxidation progressively reduces the concentration of $\mathrm{CH}_{4}$ and shifts $\delta^{13} \mathrm{C}-\mathrm{CH}_{4}$ toward heavier values. This approach was found to be well suited to Hudson Canyon (Leonte et al., 2017), which could be treated roughly as a closed system. Along the MAB, seeps are found in clusters and there is more interaction with water on the shelf, the lower continental slope, and other parts of the upper continental slope. Thus, $\mathrm{CH}_{4}$ can be introduced into or diluted as water parcels move through the area. When investigated in Hudson Canyon, a closed system Rayleigh model was deemed most appropriate even though $\mathrm{CH}_{4}$ concentrations and $\delta^{13} \mathrm{C}-\mathrm{CH}_{4}$ were periodically reset to starting values. Adopting the closed system Rayleigh model along the part of the MAB studied here means that we cannot fully resolve all the open system processes affecting $\mathrm{CH}_{4}$ in the water column, but the main drawback with the closed system model is underestimating (rather than overestimating) $\mathrm{CH}_{4}$ oxidation. The magnitude of $\boldsymbol{f}_{\boldsymbol{c}}$ is proportional to the difference between $\delta \boldsymbol{R}_{\mathbf{0}}$ and $\delta \boldsymbol{R}$, and as oxidation progresses, $\delta \boldsymbol{R}$ becomes heavier, or more positive, thus increasing the difference between $\delta \boldsymbol{R}_{\mathbf{0}}$ and $\delta \boldsymbol{R}$. Additional seep input would introduce lighter, or more negative, $\mathrm{CH}_{4}$, thus decreasing the difference between $\delta \boldsymbol{R}_{\mathbf{0}}$ and $\delta \boldsymbol{R}$ and causing the value of $\boldsymbol{f}_{\boldsymbol{c}}$ to underestimate the true amount of oxidation. Thus, the closed system approach is likely a conservative approach to assessing $\mathrm{CH}_{4}$ oxidation.

At water depths shallower than $200 \mathrm{~m}$, both gas seeps and in situ production act as sources to the water column. The $\delta^{13} \mathrm{C}-\mathrm{CH}_{4}$ measurements suggest that in situ production generates $\mathrm{CH}_{4}$ with an isotopic value of $-65.1 \%$, and the relationship between $\delta^{13} \mathrm{C}_{-} \mathrm{CH}_{4}$ and $\mathrm{CH}_{4}$ concentrations (Figure 4) shows that oxidation is readily occurring in the subsurface. The combination of dilution and microbial oxidation readily decreased $\mathrm{CH}_{4}$ concentrations close to background levels at water depths shallower than $100 \mathrm{~m}$, although surface $\mathrm{CH}_{4}$ concentrations were slightly higher than equilibrium with the atmosphere. This suggests a small flux of $\mathrm{CH}_{4}$ from the ocean to the atmosphere, despite much higher $\mathrm{CH}_{4}$ concentrations at depth. Overall, $\mathrm{CH}_{4}$ sinks readily reduce $\mathrm{CH}_{4}$ concentrations within the water column and prevent $\mathrm{CH}_{4}$ from reaching the atmosphere despite significant $\mathrm{CH}_{4}$ sources at depth.

\section{References}

Baldwin, W. E., Moore, E. M., Worley, C. R., Nichols, A. R., \& Ruppel, C. D., (2020). Marine geophysical data collected to support methane seep research along the U.S. Atlantic continental shelf break and upper continental slope between the Baltimore and Keller Canyons during U.S. Geological Survey field activities 2017-001-FA and 2017-002-FA. Retrieved from U.S. Geological Survey data release. https:// doi.org/10.5066/P9Y1MSTN

Berndt, C., Feseker, T., Treude, T., Krastel, S., Liebetrau, V., Niemann, H., et al. (2014). Temporal constraints on hydrate-controlled methane seepage off Svalbard. Science, 343(6168), 284-287. https://doi.org/10.1126/science.1246298

Brothers, L. L., Van Dover, C. L., German, C. R., Kaiser, C. L., Yoerger, D. R., Ruppel, C. D., et al. (2013). Evidence for extensive methane venting on the southeastern US Atlantic margin. Geology, 41(7), 807-810. https://doi.org/10.1130/G34217.1

Chan, E. W., Shiller, A. M., Joung, D. J., Arrington, E. C., Valentine, D. L., Redmond, M. C., et al. (2019). Investigations of aerobic methane oxidation in two marine seep environments: Part 1-Chemical kinetics. Journal of Geophysical Research: Oceans, 124, $8852-8868$. https://doi.org/10.1029/2019JC015594

Ciais, P., Sabine, C., Bala, G., Bopp, L., Brovkin, V., Canadell, J., et al. (2013). Carbon and other biogeochemical cycles. In Climate change 2013: The physical science basis. Contribution of working group I to the fifth assessment report of the intergovernmental panel on climate change (pp. 465-570). Cambridge, United Kingdom and New York, NY, USA: Cambridge University press. https://doi.org/10.1017/ CBO9781107415324.015

Damm, E., Kiene, R. P., Schwarz, J., Falck, E., \& Dieckmann, G. (2008). Methane cycling in Arctic shelf water and its relationship with phytoplankton biomass and DMSP. Marine Chemistry, 109(1-2), 45-59. https://doi.org/10.1016/j.marchem.2007.12.003

Heeschen, K. U., Tréhu, A. M., Collier, R. W., Suess, E., \& Rehder, G. (2003). Distribution and height of methane bubble plumes on the Cascadia Margin characterized by acoustic imaging. Geophysical Research Letters, 30(12), 1643. https://doi.org/10.1029/2003GL016974

Holmes, M. E., Sansone, F. J., Rust, T. M., \& Popp, B. N. (2000). Methane production, consumption, and air-sea exchange in the open ocean: An evaluation based on carbon isotopic ratios. Global Biogeochemical Cycles, 14(1), 1-10. https://doi.org/10.1029/1999GB001209 
Hovland, M., Judd, A. G., \& Burke, R. A. Jr. (1993). The global flux of methane from shallow submarine sediments. Chemosphere, 26(1-4), 559-578. https://doi.org/10.1016/0045-6535(93)90442-8

Karl, D. M., Beversdorf, L., Björkman, K. M., Church, M. J., Martinez, A., \& Delong, E. F. (2008). Aerobic production of methane in the sea. Nature Geoscience, 1(7), 473. https://doi.org/10.1038/ngeo234

Keeling, C. D. (1958). The concentration and isotopic abundances of atmospheric carbon dioxide in rural areas. Geochimica et Cosmochimica Acta, 13(4), 322-334. https://doi.org/10.1016/0016-7037(58)90033-4

Kiene, R. P. (1991). Production and consumption of methane in aquatic systems. In J. E. Rogers, \& W. B. Whitman (Eds.), Microbial production and consumption of greenhouse gases: Methane, nitrogen oxides and alomethanes (pp. 111-146). Washington DC: American Society for Microbiology.

Kvenvolden, K. A., \& Rogers, B. W. (2005). Gaia's breath-Global methane exhalations. Marine and Petroleum Geology, 22(4), 579-590. https://doi.org/10.1016/j.marpetgeo.2004.08.004

Leonte, M., Kessler, J. D., Kellermann, M. Y., Arrington, E. C., Valentine, D. L., \& Sylva, S. P. (2017). Rapid rates of aerobic methane oxidation at the feather edge of gas hydrate stability in the waters of Hudson Canyon, US Atlantic Margin. Geochimica et Cosmochimica Acta, 204, 375-387. https://doi.org/10.1016/j.gca.2017.01.009

Leonte, M., Ruppel, C.D., Ruiz-Angulo, A., \& Kessler, J.D. (2020). Water temperature, salinity, methane, methane stable isotopes, and others chemical parameters collected by CTD and Niskin bottles from research vessel Hugh R. Sharp in Mid-Atlantic Bight from 2017-08-25 to 2017-09-05. Retrieved from NOAA National Centers for Environmental Information. . https://doi.org/10.25921/pr39-4f13

Leonte, M., Wang, B., Socolofsky, S. A., Mau, S., Breier, J. A., \& Kessler, J. D. (2018). Using carbon isotope fractionation to constrain the extent of methane dissolution into the water column surrounding a natural hydrocarbon gas seep in the northern Gulf of Mexico. Geochemistry, Geophysics, Geosystems, 19, 4459-4475. https://doi.org/10.1029/2018GC007705

Mau, S., Heintz, M. B., \& Valentine, D. L. (2012). Quantification of $\mathrm{CH}_{4}$ loss and transport in dissolved plumes of the Santa Barbara Channel, California. Continental Shelf Research, 32, 110-120. https://doi.org/10.1016/j.csr.2011.10.016

McGinnis, D. F., Greinert, J., Artemov, Y., Beaubien, S. E., \& Wüest, A. (2006). Fate of rising methane bubbles in stratified waters: How much methane reaches the atmosphere? Journal of Geophysical Research, 111, C09007. https://doi.org/10.1029/2005JC003183

Nihous, G. C., \& Masutani, S. M. (2006). A model of methane concentration profiles in the open ocean. Journal of Marine Research, 64(4), 629-650. https://doi.org/10.1357/002224006778715748

Oremland, R. S. (1979). Methanogenic activity in plankton samples and fish intestines A mechanism for in situ methanogenesis in oceanic surface waters. Limnology and Oceanography, 24(6), 1136-1141. https://doi.org/10.4319/lo.1979.24.6.1136

Pataki, D. E., Ehleringer, J. R., Flanagan, L. B., Yakir, D., Bowling, D. R., Still, C. J., et al. (2003). The application and interpretation of Keeling plots in terrestrial carbon cycle research. Global Biogeochemical Cycles, 17(1), 1022. https://doi.org/10.1029/2001GB001850

Prouty, N. G., Sahy, D., Ruppel, C. D., Roark, E. B., Condon, D., Brooke, S., et al. (2016). Insights into methane dynamics from analysis of authigenic carbonates and chemosynthetic mussels at newly-discovered Atlantic Margin seeps. Earth and Planetary Science Letters, 449, 332-344. https://doi.org/10.1016/j.epsl.2016.05.023

Reeburgh, W. S. (2007). Oceanic methane biogeochemistry. American Chemical Society, 107(2), 486-513. https://doi.org/10.1021/cr050362v

Rehder, G., Leifer, I., Brewer, P. G., Friederich, G., \& Peltzer, E. T. (2009). Controls on methane bubble dissolution inside and outside the hydrate stability field from open ocean field experiments and numerical modeling. Marine Chemistry, 114(1-2), 19-30. https://doi.org/ 10.1016/j.marchem.2009.03.004

Repeta, D. J., Ferrón, S., Sosa, O. A., Johnson, C. G., Repeta, L. D., Acker, M., et al. (2016). Marine methane paradox explained by bacterial degradation of dissolved organic matter. Nature Geoscience, 9(12), 884-887. https://doi.org/10.1038/ngeo2837

Römer, M., Sahling, H., Pape, T., Bohrmann, G., \& Spieß, V. (2012). Quantification of gas bubble emissions from submarine hydrocarbon seeps at the Makran continental margin (offshore Pakistan). Journal of Geophysical Research, 117, C10015. https://doi.org/10.1029/ 2011JC007424

Ruiz-Angulo, A., Ruppel, C. D., Hatcher, G., \& Kessler, J. D. (2020). Current velocities as a function of depth measured by lowered ADCP (LADCP) on the R/V Hugh R.Sharp in the Mid-Atlantic Bight from 2017-08-25 to 2017-09-03. Retrieved from NOAA National Centers for Environmental Information. https://accession.nodc.noaa.gov/0209236

Ruppel, C. D. (2011). Methane hydrates and contemporary climate change. Nature Eduction Knowledge, 2(12), 12

Ruppel, C. D., \& Kessler, J. D. (2017). The interaction of climate change and methane hydrates. Reviews of Geophysics, 55, 126-168. https:// doi.org/10.1002/2016RG000534

Saunois, M., Bousquet, P., Poulter, B., Peregon, A., Ciais, P., Canadell, J. G., et al. (2016). The global methane budget 2000-2012. Earth System Science Data, 8(2), 697-751. https://doi.org/10.5194/essd-8-697-2016

Schaefer, H., Fletcher, S. E. M., Veidt, C., Lassey, K. R., Brailsford, G. W., Bromley, T. M., et al. (2016). A 21st-century shift from fossil-fuel to biogenic methane emissions indicated by ${ }^{13} \mathrm{CH}_{4}$. Science, 352(6281), 80-84. https://doi.org/10.1126/science.aad2705

Skarke, A., Ruppel, C., Kodis, M., Brothers, D., \& Lobecker, E. (2014). Widespread methane leakage from the sea floor on the northern US Atlantic margin. Nature Geoscience, 7(9), 657-661. https://doi.org/10.1038/ngeo2232

Socolofsky, S. A., Dissanayake, A. L., Jun, I., Gros, J., Arey, J. S., \& Reddy, C. M. (2015). Texas A\&M Oilspill Calculator (TAMOC): Modeling suite for subsea spills. In Proceedings of the Thirty-Eighth AMOP Technical Seminar (Environment Canada, Ottawa) (pp. 153-168).

Thurnherr, A. M. (2011). How to process LADCP data with the LDEO software. Versions IX.7-IX.10. https://www.bodc.ac.uk/data/documents/nodb/pdf/ladcp_ldeo_processing_IX.7_IX.10.pdf

Wang, B., Socolofsky, S. A., Breier, J. A., \& Seewald, J. S. (2016). Observations of bubbles in natural seep flares at MC 118 and GC 600 using in situ quantitative imaging. Journal of Geophysical Research: Oceans, 121, 2203-2230. https://doi.org/10.1002/2015JC011452

Weber, T., Wiseman, N. A., \& Kock, A. (2019). Global ocean methane emissions dominated by shallow coastal waters. Nature Communications, 10(1), 4584. https://doi.org/10.1038/s41467-019-12541-7

Whiticar, M. J. (1999). Carbon and hydrogen isotope systematics of bacterial formation and oxidation of methane. Chemical Geology, 161(1-3), 291-314. https://doi.org/10.1016/S0009-2541(99)00092-3

Wiesenburg, D. A., \& Guinasso, N. L. Jr. (1979). Equilibrium solubilities of methane, carbon monoxide, and hydrogen in water and sea water. Journal of Chemical \& Engineering Data, 24(4), 356-360. https://doi.org/10.1021/je60083a006 